\title{
Portal venous aneurysm
}

\author{
Rebekah Li Wei Tan (1) , Zi Qin Ng (1)
}

General Surgery, Royal Perth Hospital, Perth, Western Australia, Australia

\section{Correspondence to} Dr Rebekah Li Wei Tan; rebekah_2104@hotmail.com

Accepted 8 July 2021

\section{DESCRIPTION}

We describe a case of incidental finding of portal vein aneurysm (PVA) identified from CT scan performed for investigation of lower back pain, measuring $26 \times 32 \times 28 \mathrm{~mm}$ in a young man. He was healthy with no history of hepato-pancreatic-biliary disease nor history of heavy alcohol intake. His liver function test was unremarkable. He underwent further investigation with ultrasonography (figure 1) and MRI (figure 2). There was no evidence of liver cirrhosis on his ultrasonography. B mode ultrasonography often visualises an anechoic cyst like lesion in proximity to the porta hepatis, while, addition of a Doppler study substantiates the diagnosis of an aneurysm by revealing a non-pulsatile

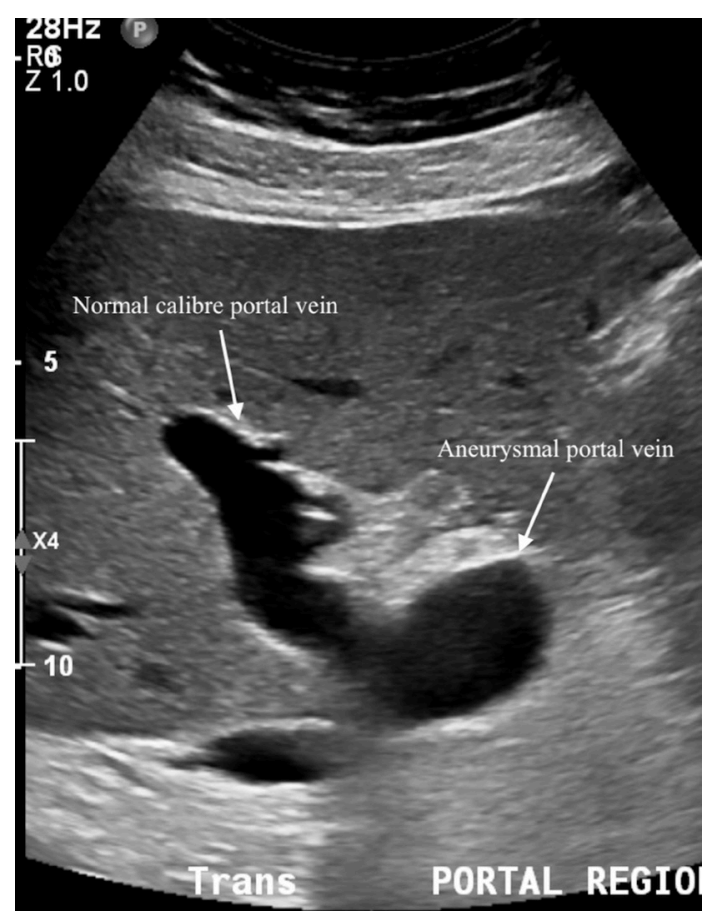

Figure 1 Ultrasound showing $26 \times 32 \times 28 \mathrm{~mm}$ aneurysmal portion of portal vein. monophasic waveform within the lesion signifying the presence of blood flow. Ultrasound is readily available and radiation-free, making it a favourable surveillance tool. CT and MRI are able to differentiate PVA from a hyperenhancing abdominal mass or a pancreatic cyst.

The aetiology of PVA is unknown with several postulated theories: (i) congenital aetiology as PVA are observed more frequently in younger age groups, (ii) weakening of the vessel wall due to trauma and pancreatitis, (iii) secondary to portal hypertension. Congenital PVA is thought to be related to its embryonic development where failure of regression in the right primitive vitelline vein leaving a diverticular remnant has been postulated to enlarge, developing into a saccular aneurysm of the portal vein later in life. ${ }^{1}$ Acquired PVA can be explained by cirrhosis and other hepatic pathologies leading to portal hypertension, intimal thickening and medial hypertrophy of the portal vein. Chronically inflamed and fibrous tissue has a weaker tensile strength, predisposing the vessel to aneurysmal dilatation. Severe pancreatitis causing autodigestion and chronic inflammation of the portal vein, trauma and invasion of the portal vein by malignancies can also lead to PVA.

Management of PVA remains somewhat controversial with options ranging from watchful waiting to surgical intervention. There are no consensus guidelines for when surgical intervention is indicated, however, should be considered if symptomatic, expanding at a rapid rate, presents a high risk of thrombosis, rupture, compression on adjacent structures or if there is evidence of biliary tract obstruction and haemobilia. ${ }^{2}$ Portacaval or mesocaval shunting to reduce portal pressure and prevent progressive dilation of PVA have been described for those with portal hypertension. ${ }^{3}$ Thrombectomy has been recommended for patients with PVA associated with thrombosis extending to the superior mesenteric and splenic veins. In those without portal hypertension, aneurysmography
Check for updates

(C) BMJ Publishing Group Limited 2021. No commercial re-use. See rights and permissions. Published by BMJ.

\begin{tabular}{l}
\hline To cite: Tan RLW, \\
Ng ZQ. BMJ Case Rep \\
2021;14:e244704. \\
doi:10.1136/bcr-2021- \\
244704 \\
\hline
\end{tabular}

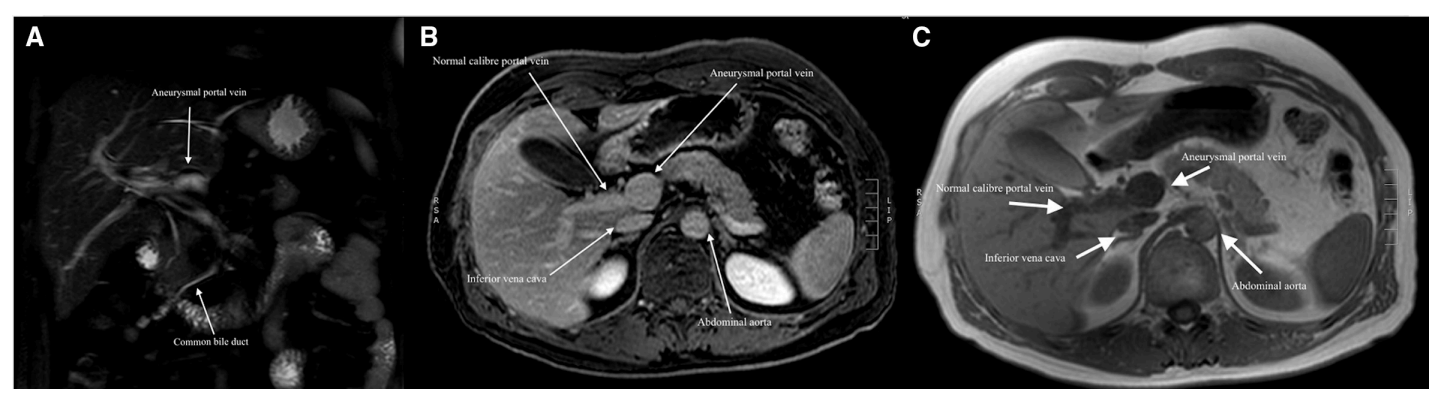

Figure 2 (A) MRI T2 SPAIR coronal; (B) MRI T1 e-THRIVE SPAIR axial and (C) MRI dual echo axial, showing aneurysmal portal vein in relation to normal calibre portal vein. 


\section{Learning points}

- Portal vein aneurysms are a rare entity that are increasingly identified incidentally due to increased availability and use of imaging studies to further investigate abdominal pain and other non-specific abdominal symptoms.

- Due to a small number of cases reported in the literature, management has not been standardised and should therefore be treated on a case by case basis.

- Watchful waiting in small slow growing aneurysms is a currently accepted treatment, however, large symptomatic aneurysms with associated complications should prompt further investigation and definitive surgical management.

and aneurysmectomy have been the preferred treatment for saccular and fusiform aneurysms respectively as it allows for the preservation of the portal circulation and reinstates laminar flow in the portal vein. ${ }^{4}$ In our case, given its relatively asymptomatic small size of PVA, we elected for surveillance with ultrasonography.
Contributors RLWT: write up of case and supporting literature; ZQN: review of case and supporting literature, case images.

Funding The authors have not declared a specific grant for this research from any funding agency in the public, commercial or not-for-profit sectors.

Competing interests None declared.

Patient consent for publication Obtained.

Provenance and peer review Not commissioned; externally peer reviewed.

\section{ORCID iDs}

Rebekah Li Wei Tan http://orcid.org/0000-0002-3664-7581

Zi Qin Ng http://orcid.org/0000-0002-6272-4640

\section{REFERENCES}

1 Gallagher DM, Leiman S, Hux CH. In utero diagnosis of a portal vein aneurysm. J Clin Ultrasound 1993;21:147-51.

2 Field Z, Madruga M, Carlan SJ, et al. Portal vein aneurysm with acute portal vein thrombosis masquerading as a pancreatic mass. Hematol Oncol Stem Cell Ther 2020. doi:10.1016/j.hemonc.2020.05.010. [Epub ahead of print: 30 May 2020].

3 Lau H, Chew DK, Belkin M. Extrahepatic portal vein aneurysm: a case report and review of the literature. Cardiovasc Surg 2002;10:58-61. doi:10.1016/S09672109(01)00104-1

4 Cho SW, Marsh JW, Fontes PA, et al. Extrahepatic portal vein aneurysm--report of six patients and review of the literature. J Gastrointest Surg 2008;12:145-52.

Copyright 2021 BMJ Publishing Group. All rights reserved. For permission to reuse any of this content visit

https://www.bmj.com/company/products-services/rights-and-licensing/permissions/

BMJ Case Report Fellows may re-use this article for personal use and teaching without any further permission.

Become a Fellow of BMJ Case Reports today and you can:

- Submit as many cases as you like

- Enjoy fast sympathetic peer review and rapid publication of accepted articles

- Access all the published articles

Re-use any of the published material for personal use and teaching without further permission

Customer Service

If you have any further queries about your subscription, please contact our customer services team on +44 (0) 2071111105 or via email at support@bmj.com.

Visit casereports.bmj.com for more articles like this and to become a Fellow 